Click www.researchjournal.co.in/online/subdetail.html to purchase.

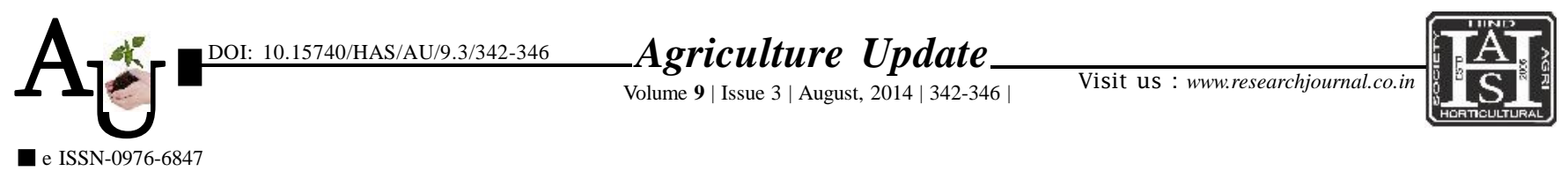

\title{
Research Article Trends in production and export performance of gingelly and gingelly oil
}

\author{
D. KUMARASAMY AND C. SEKAR
}

Article Chronicle:

Received :

04.04.2014;

Revised :

11.06.2014;

Accepted :

26.06.2014

\section{KeY Words :}

Growth rate,

Production,

Exports, Markov

chain, Gingelly, Oil
Summary : Sesame (Sesamum indicum L.), commonly known as til or gingely is the oldest oil seed crop cultivated in the world. It was reported to be originated from Africa. Sesame was introduced into India by the earliest human migrants from Africa. Gingelly occupies 0.63 lakh hectares in Tamil Nadu with an average yield of $506 \mathrm{~kg}$ per hectare. The annual production was to an exact of 0.31 lakh tonnes. India exports gingelly seeds to China, Holland, USA, Germany, Turkey, Netherlands, Hong Kong, Israel, UK and UAE. The study focused on the production and export performance of the gingelly and oil. For the study, secondary data on area, production and yield of major gingelly producing districts of Tamil Nadu were estimated for the years from 1980-2010. The export performance of gingelly and gingelly oil in India was examined using secondary data from 1995-2010. The collected data were analysed from various statistical tools viz., compound growth rate and Markov chain analysis. From the results, it was found that during 1980-2010, the growth rate was positive for production and yield of gingelly in Erode and Karur districts. Erode district showed negative trend in area of during the year 1980-1990. The decreasing area of gingelly was due to poor rainfall and high drought during the period. The results indicated that area, production and yield of gingelly were low in four districts viz., Villupuram, Tanjavur, Cuddalore and Salem due to persistent drought. The trend in gingelly export in quantity was found to be higher in the period (1980-1990). It implies that a higher quantity of gingelly is being exported during the period which increased the unit price of gingelly with marginal increase in export value. The gingelly oil was not exported during 1980-1990.Subsequently the export of oil pickedup and showed an increase ranging from 14-17 per cent, period between 1991-2010 due to the trade regime and export policies of the government. The Markov chain analysis showed that Republic of Korea was found to be one of the stable importers of Indian sesame seed because it original share of around 80 per cent over the period of 1995-2010 whereas Sri Lanka was found as one of the stable importers of Indian sesame oil because it retained its original share of around 40 per cent over the period of 1995-2010. It is concluded that Republic of Korea and Sri Lanka was the stable importer of sesame and oil from India, respectively. Because these countries have high level probability of retention.

How to cite this article : Kumarasamy, N. and Sekar, C. (2014). Trends in production and export performance of gingelly and gingelly oil. Agric. Update, 9(3): 342-346.
Author for correspondence :

\section{N. KUMARASAMY}

Department of Agricultural and Rural Management, Centre for Agricultural and Rural Development Studies, Tamil Nadu Agricultural University, COIMBATORE (T.N.) INDIA

Email: kumarasamytnau

@ gmail.com

See end of the article for

authors' affiliations 